\title{
Menemukan Formula Sinematografi Seni Pertunjukan
}

\author{
Arif Eko Suprihono ${ }^{1}$ dan Andri Nur Patrio ${ }^{* *}$ \\ Jurusan Televisi, Fakultas Seni Media Rekam, Institut Seni Indonesia Yogyakarta
}

\begin{abstract}
ABSTRAK
Fokus dari sinematografi untuk seni pertunjukan dimaksudkan untuk diskusi tentang pembuatan pilihan pencahayaan dan kamera saat merekam aktivitas seni pertunjukan di panggung untuk program televisi. Televisi adalah bentuk di mana sesuatu disampaikan, dicapai, atau ditransfer ke sejumlah besar orang. Isu 'efek' televisi kehilangan program-program yang mengarah perlu diminta tidak hanya dalam hal efek atau kegiatan penonton tetapi juga dalam hal kesempatan yang hilang bagi keanekaragaman budaya yang akan diekspresikan pada kreativitas televisi. Setiap aspek dari televisi menunjukkan ketergantungan pada genre, yang merupakan kelompok kategoris proses diskursif yang transek teks melalui interaksi budaya mereka dengan industri, penonton, dan konteks yang lebih luas. Kita mungkin mulai diskusi dengan memulai dengan contoh tekstual seperti ketoprak humor, wayang kulit, opera van java sebagai praktek industri, pergeseran sejarah, atau kontroversi penonton.
\end{abstract}

Kata kunci: sinematografi, seni pertunjukan, ketoprak humor

\section{ABSTRACT}

The Formula of Performing Arts Cinematography. The focus of cinematography for performing arts is intended to a discussion about the making of lighting and camera choices when recording performing arts activities on stage for the television programs. Television is the form in which something is conveyed, accomplished, or transferred to a large number of people. The issues of 'the effects' of television miss leading programs needs to be asked not only in terms of effects or audience activity but also in terms of missing opportunities for cultural diversity to be expressed on television creativities. Every aspect of television exhibits a reliance on genre, which are categorical clusters of discursive processes that transect texts via their cultural interactions with industries, audiences, and broader contexts. We might begin a discussion by starting with a textual example such as ketoprak humor, wayang kulit, opera van java as an industrial practice, a historical shift, or an audience controversy.

Key words: cinematography, performing arts, cultural values, aesthetical consideration, television effects

\section{Pendahuluan}

Televisi sebagai salah satu agent perubahan bagi kebudayaan bangsa Indonesia memiliki potensi besar untuk berperan aktif dalam menyeleksi dan menjaga kelestarian seni pertunjukan tradisional Indonesia yang menjadi identitas keunggulan di antara bangsa-bangsa dunia. Dalam peran yang sedemikian penting, diasumsikan bahwa aktivitas dan perkembangan industri pertelevisian perlu memiliki "pedoman khusus" yang menjadi rujukan bagaimana semestinya memberlakukan seni pertunjukan tradisional yang tersebar di seluruh nusantara, karena bangsa ini mengakui bahwa keunggulan komparatif seni pertunjukan telah menjadi salah satu wujud identitas suku bangsa yang sangat penting bagi pelestarian karakteristik dan kearifan lokal. Persoalan yang serius, jika saja hegemoni industri pertelevisian menjadi ancaman bagi arah dan keberlanjutan kebudayaan yang memiliki kekhasan dan keunggulan bangsa
Indonesia. Oleh karenanya, model sinematografi materi siaran televisi diduga keras menjadi salah satu kunci penting untuk dapat masuk pada identitas tayangan televisi yang berkarakter dan unggul dalam menjaga, melestarikan, mengemas seni pertunjukan tradisional suku-suku bangsa Indonesia di era multimedia.

Fakta industri pertelevisian Indonesia telah mengangkat banyak hasil karya cipta masyarakat yang tergolongkan dalam kesenian tradisional memang tidak terbantahkan. Akan tetapi, sebagai satu konsekuensi perilaku budaya masih diperlukan sebentuk 'social control' atas kinerja lembaga penyiaran publik ini. Oleh karena itu, diperlukan penelitian yang dilatarbelakangi oleh fakta lapangan dalam materi tayangan program televisi yang kurang optimal dalam mengemas seni tradisional nusantara. Banyak sekali potensi seni pertunjukan yang tidak dapat diungkap secara lengkap dalam program penyiaran televisi.

1 Alamat korespondensi: Prodi Televisi, FSMR, ISI Yogyakarta. Jalan Parangtritis KM. 6,5, Sewon, Yogyakarta. Telepon +628562567879 e-mail: arifeko@yahoo.com 


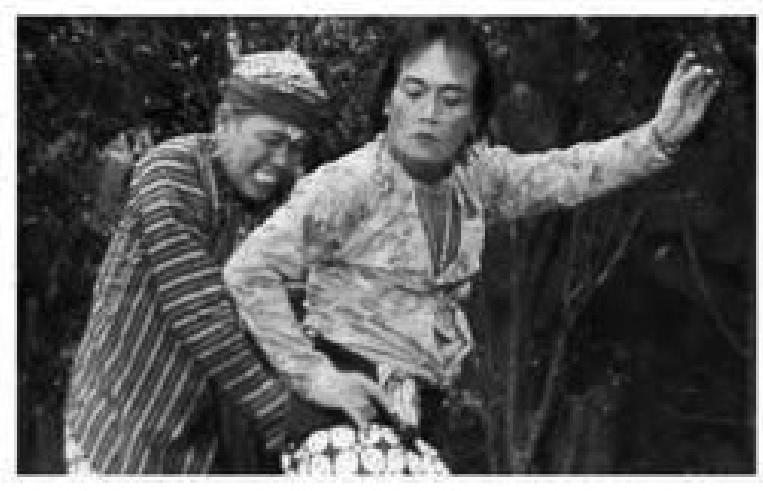

Catatan: Gambar diunduh dari koleksi gambar google, 'ketoprak humor'.

Yang dimaksud adalah adanya 'kecacatan' estetika seni tradisi akibat diformat secara sepihak oleh pelaku industri televisi. Seperti contoh kasus, program siar Ketoprak humor di RCTI beberapa tahun yang lalu. Sangat terlihat dalam kasus ketoprak humor terjadi kesalahan interpretasi estetika pemanggungan, yang berakibat pada distorsi estetika akibat transformasi panggung pertunjukan. Ketoprak dalam 'pedoman estetika lokal' tidak saja menunjukkan tampilan yang lengkap dengan musik pengiring dan seluruh dekorasi panggung, tetapi juga menunjukkan tingkat kesempurnaan ungkap tanpa harus dilebih-lebihkan unsur banyolan-nya. Ditonjolkannya unsur humor dalam format program televisi lebih didesak oleh kebutuhan esensial industri televisi sebagai media hiburan massal. Akibatnya, masyarakat mengetahui benar bahwa ketoprak kehilangan fungsi edukatif dan filosofisnya dalam mengupas lakon yang biasa ditampilkan di panggung konvensional.

Fakta lain yang layak disajikan sebagai latar belakang pentingnya pengkajian akademis adalah pergeseran estetika pergelaran seni pertunjukan wayang kulit, yang jauh merombak 'tradisi pergelaran' dengan pola pementasan studio televisi. Pola pikir masyarakat secara revolusif berubah pada saat memaknai pergelaran wayang dengan formula pemanggungan televisi. Bukti perubahan 'paradigma estetika' dalam menata panggung wayang kulit antara lain: (1) Ada perubahan arah menonton yang sangat ekstrem. Estetika tradisional wayang kulit dominan dinikmati dari balik layar sehingga wayang tampak sebagai bayang-bayang hitam yang tampak sebagai wujud bayangan figur tokoh boneka yang terkena terpaan sinar blencong. Pada

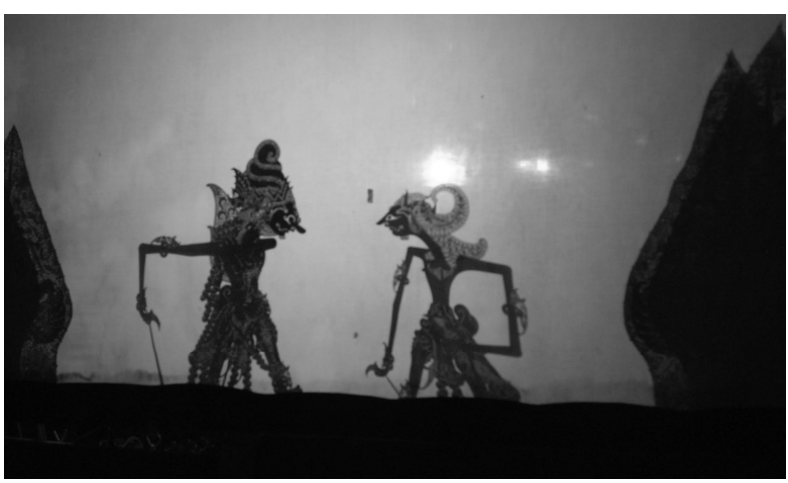

Catatan: Foto koleksi pribadi Arif Eko Suprihono, potret pementasan wayang kulit di BPSNT Yogyakarta.

garapan estetika panggung pertelevisian, kamera sebagai pengganti sudut pandang penonton ditempatkan lebih dominan dari arah belakang dalang. Dengan demikian, penyajian wayang terlihat fisikal dengan wujud asli boneka wayang (bukan lagi bayang-bayang atau wewayangan); (2) Sudut pandang yang diformat dari camera angle dalam pergelaran wayang kulit, bahkan harus mengubah tempat duduk para sindhen atau vokalis pendukung. Mereka sengaja ditempatkan di dekat gedebog tempat menancapkan wayang. Posisi ini dimaksudkan oleh tim kreatif industri televisi untuk memberikan sudut pandang yang tepat bagi arah bidikan kamera; (3) Struktur dramatik pemanggungan yang memberikan keleluasaan bagi para dalang untuk berekspresi, seperti menghadirkan tokoh cangik dan limbuk dengan adegan khusus limbukan, yaitu adegan yang sengaja memberikan kelonggaran untuk interaksi antara tokoh dalang dengan para sinden, ataupun bahkan tokoh komedian lain yang sengaja diundang dalam pergelaran wayang. Proporsi adegan limbukan lebih didasarkan pada kebutuhan menghibur jika dibandingkan dengan fungsi edukatif di balik narasi cerita utama lakon yang dipentaskan; (4) Layar tempat untuk memainkan wayang, secara ekstrem juga diperlebar dengan sangat panjang rentangnya. Hal ini dimaksudkan untuk membuat semacam drapery untuk menciptakan background bagi sudut arah tembak kamera pada permainan wayang ki dalang.

Komponen struktur sajian yang berubah inilah yang setidaknya mudah dilihat dari sisi fisik sajian pementasan wayang kulit tradisional. Belum lagi dengan munculnya kualitas pemanggungan baru dengan keterampilan teknik mendalang 


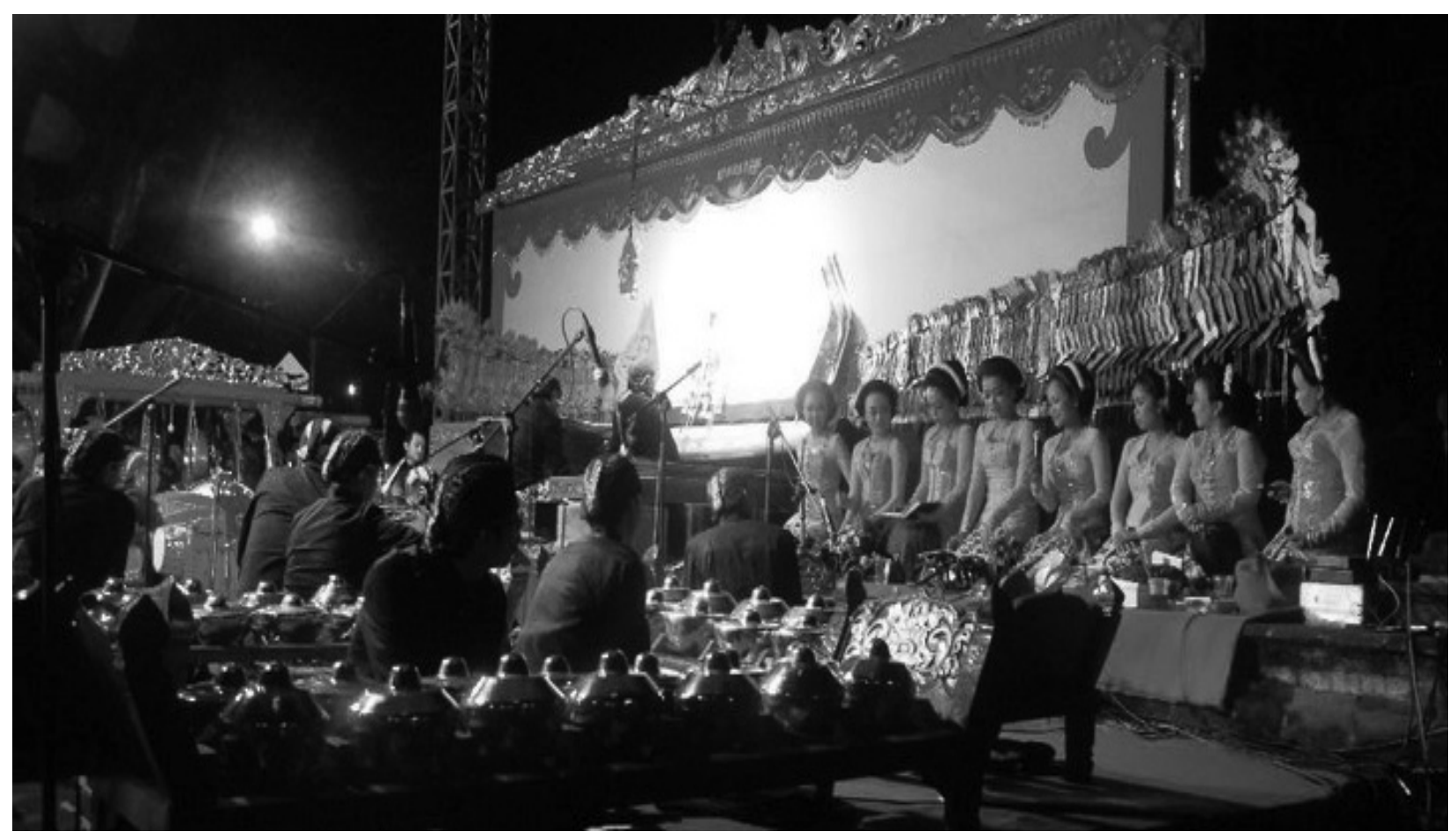

Catatan: Foto koleksi pribadi Arif Eko Suprihono, potret pementasan wayang kulit di Monumen Satu Maret Kilometer Nol, Pusat Kota Yogyakarta.

yang menonjolkan gerakan ekspresif dalang pada saat mengangkat boneka sebagai alat pewujud gerak. Eksplorasi gerakan wayang tidak sebatas pada pakem pakeliran gerak yang menyamping ke arah kanan atau ke kiri dalang saja, tetapi secara eksploratif ditemukan gerakan-gerakan salto untuk menambah nuansa atraktif gerakan boneka. Gerakan memutar di tempat dengan poros gerak horizontal ini menunjukkan bahwa dalang menguasai pola sabet wayang yang tidak saja mengarah horizontal, tetapi bahkan bergerak ke arah vertikal dengan segala variasi putaran.

Tidak luput dari eksplorasi kreatif para pekerja media, dengan menghadirkan Opera van Java, yang dengan sangat longgar memainkan sumber cerita yang bernuansa tradisional, bahkan komtemporer yang benar-benar memberikan keleluasaan bagi para peran tokoh untuk berekspresi. Penempatan kamera pada pergelaran OVJ menunjukkan bahwa seni tradisional cukup dikuasai dengan sudut pandang kamera yang berada di tiga titik utama panggung dan ditambah dengan permainan variasi level angle camera.

Banyak seni pertunjukan tradisional nusantara yang terabaikan daribidikan kamera televisi. Hal ini diduga karena semata-mata kurang informasi dan keterbatasan format sajian seni pertunjukan, yang secara lebih serius dapat diasumsikan menjadikan pengaruh negatif pola hiburan masyarakat yang kurang peduli pada seni pertunjukan tradisi dan bergeser pada seni pertunjukan televisi yang jauh dari karakter bangsa karena terlalu banyak sajian tayang yang diimport dalam jumlah tak sebanding.

\section{Pentingnya Sebuah Kajian}

Studi pustaka dan pencermatan terhadap fenomena diangkatnya seni pertunjukan tradisional di layar kaca setidaknya dapat diarahkan sebagai proses studi intensif yang bermanfaat untuk menjawab persoalan teknis antara lain (a) Mencermati dan mengidentifikasi model sinematografi seni pertunjukan tradisional Indonesia yang sementara ini dipakai dalam format program tayangan televisi. Identifikasi mencakup evaluasi kelebihan, kekurangan, dan peluang yang mungkin dikenali dengan mudah sebagai potensi seni pertunjukan media televisi; (b) Mengidentifikasi potensi seni pertunjukan tradisional Indonesia yang tidak direkam dan disiarkan oleh industri pertelevisian. Kearifan lokal dan karakteristik seni pertunjukan tradisional perlu diformulasikan dengan lebih jelas agar lebih banyak dikenali oleh para pelaku industri media televisi; (c) Menemukan formula sinematografi seni pertunjukan tradisional Indonesia yang khas agar interaksi kebudayaan Indonesia dan dunia 


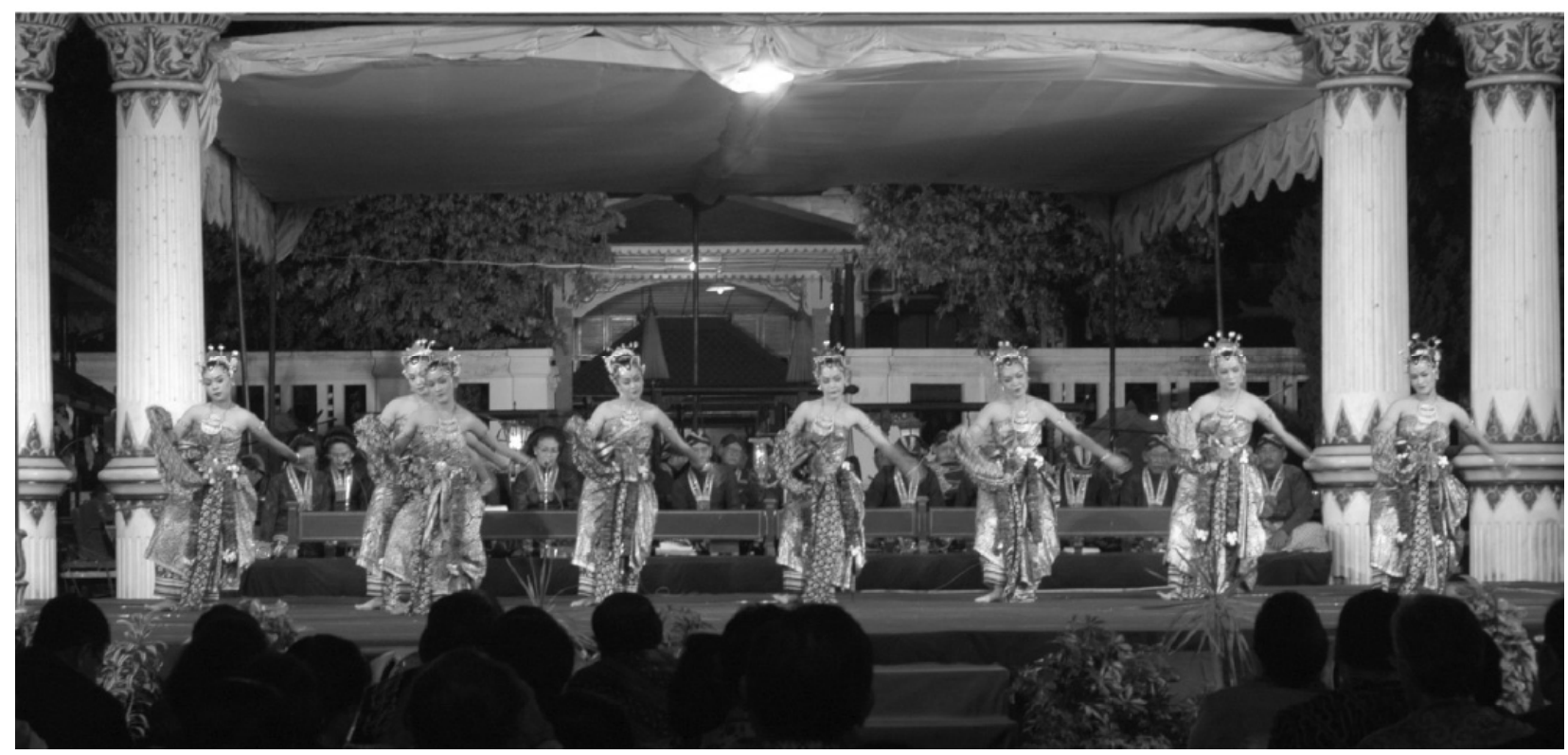

Catatan: Foto koleksi pribadi Arif Eko Suprihono, potret pementasan Bedaya di Panggung Pagelaran Kraton Yogyakarta.

penyiaran publik dapat bersinergi dengan baik. Penemuan dan formulasi model sinematografi ini dapat dikaji secara berkelanjutan untuk karakter budaya penyiaran di masa yang akan datang; (d) Menyusun bahan ajar bagi para pembelajar seni media rekam dalam menghadapi keunikan dan keunggulan seni pertunjukan tradisional Indonesia yang tersebar di seluruh wilayah nusantara.

Studi pencermatan terhadap fakta program tayang televisi ini sangat penting didesain untuk menunjukkan keutamaan dalam fungsi aplikatif budaya massa dan pengelolaan karakter bangsa melalui media penyiaran. Keutamaan dari kinerja akademik ini adalah (1) penelitian aplikatif mengenai industri kreatif melalui media penyiaran belum pernah dilakukan dengan terstruktur, sistematis, dan berkesinambungan; (2) Jurusan Televisi, FSMR, ISI Yogyakarta perlu mensosialisasikan produk akademik di kalangan yang lebih luas dengan berperan aktif dalam mengawasi interaksi pelaku seni pertunjukan dan pelaku dunia usaha media penyiaran. Fungsi sosial sebagai dinamisator dan pemantau interaksi sosial ini menjadi penting karena perguruan tinggi tidak semestinya kehilangan peran aktifnya akibat kesibukan akademis di lingkungan internal; (3) Studi teknik sinematografi ini akan memberikan pemahaman yang lebih baik terhadap seni pertunjukan tradisional pada saat dipertimbangkan menjadi salah satu tayangan media siaran. Pola seleksi dimensi estetis seni pertunjukan tradisional yang memiliki keunikan dan kearifan lokal perlu diperhitungkan dalam formula sinematografi normatif, tetapi memiliki keunggulan khas budaya nusantara. Di sisi lain, para pengolah program televisi perlu sekali memperhitungkan fungsi sosial seni pertunjukan tradisional di kalangan masyarakat pendukung. Memaparkan fungsi dengan pemahaman yang lebih komprehensif sehingga ada transfer of knowledge di lingkungan yang lebih luas. Karena televisi diyakini sebagai media penyiaran publik yang mampu mendiseminasikan informasi tanpa kendala geografis dan demografis.

\section{Esensi Substansial Persoalan Sinematografi}

Interaksi dunia penyiaran televisi dengan seni pertunjukan tradisional Indonesia perlu dicermati dengan analisis pemanfaatan kamera. Jika kerja ilmiah dalam melakukan analisis ini secara tersistematisasi dapat dilakukan, kegiatan itu pasti dapat menjadi peluang untuk menjawab esensi persoalan sebagai berikut (1) Apakah ada kendala teknik estetik pengelola industri kreatif televisi pada saat mengangkat seni pertunjukan tradisional sebagai materi tayang? (2) Apakah interaksi pelaku seni pertunjukan tradisional dan pelaku industri kreatif pertelevisian sudah terjadi sinergi gagasan, perilaku, dan apresiasi? (3) Apakah diperlukan formula sinematografi tertentu jika harus mengoptimalisasikan penayangan seni pertunjukan tradisional? (4) Apakah 
ada korelasi positif antara penayangan seni pertunjukan tradisional dengan karakteristik kehidupan berbangsa dan bernegara? (5) Apakah diperlukan bahan rujukan yang berisi informasi sinematografi seni pertunjukan tradisional bagi para pelaku seni (praktisi, akademisi, pembelajar, pengelola kebudayaan)?

Studi potensi kamera ini sengaja mengangkat dan mendalami istilah sinematografi dibandingkan dengan videografi. Perlu untuk disadari sepenuhnya, bahwa tujuan dari pembahasan dua istilah ini bermuara pada teknik mengontrol elemenelemen penciptaan gambar untuk mendapatkan struktur estetis yang memiliki kekhasan dalam satu rangkaian produksi. Upaya mengontrol dan mengendalikan elemen-elemen penciptaan gambar ini dimaksudkan untuk mengembangkan cerita yang sedang disajikan di depan penonton. Istilah-istilah seperti framing, camera movement, staging of action, lighting control adalah beberapa dari sedemikian banyak istilah yang dipergunakan oleh pengarah acara, director of photography, dalam mewujudkan kreativitasnya dengan kamera.

Sinematografi dibentuk dari kata kinema (bahasa Yunani) yang berarti gerakan dan graphein dimaknai secara bebas dengan melukis, merekam. Sebagai jenis aktivitas fotografi, sinematografi merupakan produk motion photography. Oleh karena aktivitas dan produknya, sinematografi memiliki tambahan kesulitan teknik yang mencakup gerakan kamera dan kemungkinan kreativitas yang disebabkan oleh variasi gerakan itu.

Aktivitas studi potensi kamera harus berproses melalui tahapan pemahaman beberapa buku yang ditemukan dan dinilai memiliki kontribusi yang mendasar. Seperti buku Joseph V. Mascelli yang membahas tentang teori dasar sinematografi. Kependekan kata menjadi lima ' $\mathrm{C}$ ' dalam sinematografi yang dimaksud adalah camera angles, composition, continuity, close up, dan cutting. Pemahaman dasar terhadap kaidahkaidah sinematografi ini akan sangat penting bagi penayangan seni pertunjukan di layar televisi. Artinya dapat diyakini bahwa dalam memproduksi program acara televisi penerapan sinematografi menjadi ujung tombak segala perhitungan kualitas tayangan.

Mascelli mengungkapkan bahwa penempatan kamera merupakan penetapan sudut pandang penonton dalam mengamati objek. Oleh karena itu, penempatan kamera menjadi masalah mendasar agar hasil bidik yang didapatkan memberikan kesan alami sebagaimana penonton hadir langsung di tempat kejadian. Kamera yang ditempatkan secara benar dan penuh pertimbangan akan memberikan tampilan pencahayaan, blocking subjek gambar, sampai dengan komposisi subjek pada layar.

Tindakan menganalisis konsep-konsep dasar pengertian sinematografi dengan materi seni pertunjukan yang lengkap dari sisi materi seni, pelaku seni, pemanggungan, sampai dengan interaksi panggung dan penonton menjadi hal yang menarik dan informatif. Di satu sisi, pemahaman prinsip sinematografi sangat penting bagi pekerja kreatif media penyiaran. Di sisi lain sangat diperlukan pemahaman yang mendalam terhadap objek sajian yang akan dikemas. Pergulatan kreatif dalam mengantisipasi sajian seni pertunjukan tradisional dalam proses produksi akan menjadi salah satu informasi penting bagi studi format program acara televisi. Hal ini diyakini karena tidak banyak produk tayang seni pertunjukan tradisional yang berhasil menarik perhatian publik dan bahkan menjadi pilihan dalam pola rekreatif keseharian. Pemahaman seni pertunjukan secara sederhana haruslah mengetahui komponen yang terlibat di dalamnya, seperti materi seni, pelaku seni, penanggung jawab seni, penonton, sarana pendukung, manajemen pendukung dan sumber dana pendukung kegiatan. Dari ketujuh komponen ini karakteristik seni pertunjukan dapat diperhitungkan keberadaannya.

Mencermati buku Naratama (2004: 30-41) yang berjudul Menjadi Sutradara Televisi terdapat panduan yang menarik dalam mempelajari teknik penyutradaraan untuk layar kaca. Bagaimanapun, televisi merupakan 'panggung baru' bagi seni pertunjukan dan kehadiran program tayangan televisi harus mampu mengemas berbagai persoalan esensial dari estetika seni pertunjukan. Ulasan terhadap buku ini mencakup hal yang layak dipahami dalam proses analisis model sinematografi.

Buku ini cukup lengkap dan bersifat mendasar dalam pembahasan pengarahan acara televisi. Sebagai praktisi dan akademisi, penulis buku mampu memaparkan persoalan hakiki yang layak untuk ditumbuhkan dan ditekuni oleh siapa saja yang memiliki perhatian terhadap penciptaan 
program acara televisi. Statemen mendasar yang pantas dikutip antara lain: "Sering kali saya melihat kegagalan-kegagalan penyutradaraan televisi yang disebabkan oleh lemahnya sikap kepemimpinan. Padahal, kemampuan dan kreativitasnya cukup memadai."

Buku ini membahas kompetensi sutradara pentas dan pengarah acara; peran dan tanggung jawab pengarah acara, format acara televisi, sampai dengan contoh keterampilan dasar yang harus dilatih pada saat berhadapan dengan peralatan teknik televisi. Kontribusi buku ini dalam penelitian dapat dilihat dalam pembahasan element of the shot; floor plan; tips untuk kreativitas acara. Dengan menyarikan buku Ray Thompson, Naratama menuliskan (2004:79-101) bahwa element of shot merupakan formula yang berisi makna atau arti sebuah shot yang terdiri atas unsur motivasi, informasi, komposisi, sound, camera angle, continuity. Informasi ini akan lebih banyak dikupas dalam menemukan formula sinematografi seni pertunjukan tradisional yang secara komparatif akan disejajarkan dengan beberapa buku teknik lain, seperti the Five C's of Cinematography tulisan Josepth V. Mascelli. Informasi Naaratama tentang floor plan akan sangat penting dalam menetapkan gaya sajian seni pertunjukan di televisi. Ada perbedaan mendasar yang harus disadari saat mengolah kreativitas seni pertunjukan tradisional untuk televisi, yakni ruang tiga dimensi semu yang harus diperhitungkan dengan cermat saat melakukan camera blocking dan menetapkan floor plan. Realitas panggung yang akan diangkat di layar televisi perlu diperhitungkan secara khusus.

Ada pengetahuan penting yang dikemukakan oleh Paul Wheeler, seorang tokoh, praktisi yang berpengalaman luas dalam dunia kreatif film dan televisi. Sebagai anggota British Society of Cinematographers (BSC), anggota Guild of British Camera Technicians (GBCT) dan British Kinematograph, Sound and television Society (FBKS), dia telah cukup banyak menulis buku. Wheeler (2009:xix) menulis ulang High Definition Cinematography dalam edisi ketiga. Hal ini berarti bahwa buku ini cukup memberikan manfaat dan pencerahan para penggunanya. Berikut kutipan pendahuluan buku yang sangat menarik untuk dicermati dari Wheeler,
The future is bright, very bright. If the work of future Directors of Photography can be recorded in some form of very high image quality, and it matters not on what recording format or what it is recorded on, we Cinematographers have a wonderful future to look forward to. Cinematography is a craft, and often an art form, which will be needed no matter what means science uses to record the Cinematographer's work.

Buku ini membahas multicamera shots, display quality, dan picture quality. Tiga informasi ini sangat penting untuk proses studi kamera ini. Seperti pengalaman yang dituliskan, bahwa kualitas gambar biasanya sangat tajam dengan range tonal yang panjang, dan warna alami sebagaimana yang terlihat di monitor atau diproyeksikan secara digital. Kualitas gambar bagus ketika tidak ada scratching, gambar stabil, dan sesuai dengan tuntutan script. Untuk memiliki standar kualitas yang tinggi, filter defusi dapat digunakan untuk mengurangi derajat kerusakan gambar akibat warna yang terlalu tajam.

Pencermatan terhadap kinerja director of photography, pengarahan acara harus lebih lengkap dan komprehensif. Studi potensi kamera dalam aplikasi pemanggungan seni pertunjukan haruslah dengan sadar mencakup banyak hal teknis. Apa yang harus disadari seseorang pada saat bertindak sebagai dop? Buku ini merumuskan, pertama, kepercayaan untuk bekerja sebagai director of photography berarti memiliki kesempatan untuk menunjukkan kualitas kreatif dengan pekerjaan baru. Kedua, untuk karya televisi, kualitas gambar perlu ditingkatkan agar di masa yang akan datang bisa dipakai untuk kontribusi di beberapa televisi yang berbeda. Hal ini memiliki risiko sedikit menaikkan anggaran produksi. Ketiga, jika produser program cukup lentur untuk tim kreatif yang dilibatkan, merupakan kesempatan untuk memilih personel yang akrab dan memiliki kualitas kerja teruji. Keempat, pekerjaan yang dipercayakan memberi kesempatan untuk menempatkan diri sebagai pekerja kreatif yang semakin produktif.

Buku ini juga memberikan pelajaran yang baik mengenai teknik meningkatkan kualitas shot yang mapan; memberikan anjuran untuk menyediakan stok rekaman lebih banyak daripada yang diperlukan, teknik mengelola 
kamera. Secara lengkap buku ini memberikan penjelasan mengenai aspek komposisi yang mencakup framing, angle and moves, lighting, rules of thumb. Buku ini juga membahas aspek continuity yang dapat diterapkan langsung sebagai bahan pembanding pada saat mencermati buku rujukan lain.

Salah satu topik yang menarik dalam sisi akademik bidang kajian televisi adalah mencermati hubungan interaktif antara penonton dan televisi. Yang dimaksud adalah hubungan interaksi ditempatkan sebagai fakta sosiobudaya, bahwa televisi memiliki domain kultural yang sangat penting. Jika dipahami, pengaruh televisi cukup besar dan dapat memberikan wacana pada dunia realitas kehidupan yang sangat bertolak belakang dengan kehidupan penonton. Fokus terhadap impresi penonton saat mengikuti tayangan seni pertunjukan tradisional dapat digolongkan sebagai salah satu pemahaman tradisi konvergensi penelitian.

Buku yang ditulis oleh Bernadette Casey (2008:x) berjudul Television Studies: The Key Concepts sangat menarik dan inspiratif terhadap arah pengelolaan pencermatan kasus studi kamera ini. Buku ini dimaksudkan sebagai peta studi televisi, yang isinya mengandaikan sebagai peta teritorial dan mengindikasikan model-model studi televisi. Oleh sebab format program televisi dalam mengemas seni pertunjukan memiliki fungsi kultural sebagai kegiatan pendokumentasian bagi sejarah seni pertunjukan, ada banyak informasi yang harus dipahami sebagai kinerja kreatif berdasarkan fakta lapangan. Buku Barry Hampe (1997:93-98) Making Documentary Films and Reality Videos memberikan banyak pemahaman terhadap berpikir kreatif dan bertindak cerdas dalam mengelola film dokumenter dan video realitas. Sebagai tuntunan untuk merencanakan, merekam, dan mengedit peristiwa kemasyarakatan buku ini sangat lengkap. Buku ini tidak hanya memulai deskripsi dari penjelasan pola berpikir filmis, tetapi juga mengarahkan pokok-pokok pikir yang hakiki dalam menangani program dokumenter.

Konteks aplikatif dalam penemuan model sinematografi ini lebih tegas mengarah pada fungsi sosiohistoris karya tayang seni pertunjukan tradisional di televisi. Pola pikir yang meyakini bahwa seni pertunjukan tradisional harus dapat diangkat secara 'utuh' di layar kaca antara lain menunjukkan semangat dokumenter dalam fungsi praktis. Bagaimana merekam kebiasaan manusia yang berkesenian merupakan entri penting dalam framing program televisi. Meskipun demikian, para pekerja televisi juga memiliki kendala teknis estetis dan kode etik kelembagaan yang tidak terlalu longgar saat berhadapan langsung dengan tuntutan estetika seni pertunjukan.

Inti penjelasan dalam buku ini cukup lengkap menyangkut manajemen produksi program dokumenter seperti: (1) Tahap praproduksi membahas tahapan langkah produksi, mengembangkan gagasan inti materi dokumenter, menuliskan naskah secara lengkap, sampai dengan menetapkan tim kreatif yang harus disusun sebagai persiapan awal karya documenter; (2) Tahap produksi membahas lebih rinci tentang teknik merekam data visual dan auditif, bagaimana bekerja secara bijak di lokasi perekaman, bagaimana mengarahkan narasumber untuk beraksi dalam karya dokumenter secara objektif, sampai dengan berbagai pertimbangan teknik produksi; (3) Tahap pascaproduksi menjelaskan bagaimana kegiatan editing dikelola secara benar dan sesuai dengan rencana produksi, persiapan kerja pascaproduksi yang harus dilakukan secara terpantau, sampai dengan kerja penyelesaian (finishing touch) saat karya dokumenter sudah selesai dikerjakan. Bagaimana mendistribusikan karya juga merupakan pokok perhatian penting penulis buku ini.

Meski tidak harus berpretensi untuk menggurui banyak pihak yang terlibat dalam studi televisi atau bahkan juga pada pelaku kreatif industri televisi, perlu lebih jauh disiapkan banyak informasi budaya lokal yang pemahamannya memerlukan pencermatan-pencermatan teoretikal. Artinya, teori budaya seharusnya menjadi acuan yang mendasar. Dengan demikian, akan ada temuan baru bagaimana semestinya kinerja kreatif menjadikan informasi budaya masyarakat lebih mengarah pada kualitas karakter hidup berbangsa.

Esensi yang menarik juga bersumber dari buku teks yang ditulis oleh David Kaplan dan Robert A. Manners (2002:128-130) tentang teori antropologi dengan judul Teori Budaya. Buku ini cukup menarik untuk dijadikan rujukan penelitian ini. Penelitian yang harus melibatkan interpretasi atas budaya tradisional masyarakat oleh sekelompok pekerja kreatif media penyiaran 
merupakan salah satu lahan analisis antropologi. Meski demikian, dari sisi sosiobudaya, peneliti tidak berpretensi masuk terlalu jauh dalam analisis yang bersifat antropologis. Bahkan secara meluas studi kamera perlu lebih berfokus pada teknis kreatif dalam mengemas seni pertunjukan tradisional dengan mencermati berbagai model sinematografi yang sudah dilakukan oleh beberapa lembaga penyiaran terpilih.

Pemahaman terhadap beberapa penjelasan mengenai teori kebudayaan yang dibahas, sangat membantu untuk lebih hati-hati melihat fenomena yang terjadi di ranah kognitif, dan afektif persoalan sinematografi seni pertunjukan tradisional. Yang menarik lebih jauh dipahami, bahwa disiplin ilmu antropologi memiliki kekayaan orientasi teoretik yang dapat dirunut secara jelas. Oleh sebab keunggulan ini, peneliti terpanggil untuk dapat menerapkan salah satu teori yang menjadi titik pijak dialektikal antara seni pertunjukan dan seni media penyiaran.

Alternatif untuk menerapkan analisis formal baik dalam strukturalime maupun dalam pendekatan fenomena budaya akan sangat bermanfaat untuk menjembatani dialog kreatif antara seniman panggung dan pekerja kreatif media.

\section{Sulih Panggung Sulih Mata}

Seni pertunjukan bagi masyarakat pendukungnya adalah sebuah produk kreativitas, identitas diri, dan bahkan tingkat kualitas peradaban. Jika suatu seni pertunjukan mampu bertahan dalam durasi waktu lebih dari 25 tahun secara terus-menerus dalam suatu aktivitas sekelompok orang, masyarakat menyebutnya sebagai sebuah aktivitas yang mentradisi. Karena interaksi seni pertunjukan sangat dipengaruhi oleh kehidupan masyarakatnya, wajar jika ada konsekuensi sosiologis pada saat memilih dan menempatkan di layar kaca.

Untuk memahami seni pertunjukan secara sistematis, perlu sebuah kerangka pikir. Bahwa pada kenyataannya seni pertunjukan ditopang oleh komponen pendukung, yakni materi seni, pelaku seni, penanggung jawab seni, penonton, sarana pendukung, dana pendukung, dan manajemen produksi. Materi seni pertunjukan menunjuk pada medium presentasi, gaya penyajian, dan pesan (content). Medium gerak, suara, bunyi, dan rupa dapat dimanfaatkan secara terpisah atau bercampuran untuk sebuah keutuhan bentuk estetis dalam menyampaikan pesan kepada penonton. Gaya penyajian sangat ditentukan dan bahkan dipengaruhi oleh kaidahkaidah estetika yang sengaja diterapkan oleh para pelaku dan penanggung jawab seni. Pelaku seni menunjuk pada seseorang atau sekelompok orang yang secara sadar bertugas untuk menyajikan materi seni yang telah diciptakan dengan berbagai jenis kreativitas oleh para penanggung jawab seni. Pelaku seni dan penanggung jawab seni bisa menyatu dalam satu figur seseorang. Akan tetapi, tidak menutup kemungkinan, pada tahap kehidupan kesenian yang mengarah pada profesionalitas individual mengakibatkan ada pemisahan tugas dan tanggung jawab sebagai sebentuk kompetensi. Pelaku seni menjadi lebih bersifat praktisi, sementara penanggung jawab seni lebih dibebani tugas konseptual dan kreatif desain.

Seni pertunjukan selalu memerlukan penonton. Jenis dan karakteristik penonton akan senantiasa menjadi pokok orientasi kreatif bagi penanggung jawab seni. Dalam komunitas seni pertunjukan tradisional, penonton adalah masyarakat pendukung. Masyarakat yang menghidupi dan memberikan waktu untuk berolah fungsi kultural. Sarana pendukung menunjuk pada berbagai bentuk teknologi pendukung, baik dalam pemanggungan, rias dan busana, tata lampu, tata suara, sampai dengan properti yang erat kaitannya dengan penampilan tokoh dari cerita yang disajikan. Perkembangan teknologi dalam sarana dan prasarana pendukung mencerminkan rentang waktu aktivitas seni pertunjukan. Teknologi manual sampai dengan teknologi masinal, atau bahkan teknologi digital, adalah bukti fisikal pendukung aktivitas berkesenian. Dalam perkembangan terakhir, seni pertunjukan sangat hingar bingar dalam mengeksploitasi kemajuan teknologi tepat guna yang dipergunakan dalam mendukung sajian pementasan.

Komponen dana pendukung menunjuk pada jenis-jenis sumber keuangan yang dikelola dalam sebuah produksi pertunjukan. Setidaknya dikenali ada tiga jenis dana pendukung seni pertunjukan, yang masing-masing memiliki karakteristik dan keunggulan tersendiri. Ketiga jenis dana pendukung itu adalah jenis communal support, government support, dan commercial 
support. Diterapkan atau dipilihnya sumber dana pendukung dari ketiga jenis ini akan membawa pengaruh pada pilihan dan desain manajemen pertunjukan yang harus dikelola oleh masyarakat.

Rumusan sederhana, sulih panggungsulih mata, sesungguhnya ingin menunjukkan pentingnya formula pada saat mengolah seni pertunjukan agar dapat ditayangkan di layar kaca. Bagaimanapun juga ada perbedaan yang sangat esensial dalam perbandingan panggung pertunjukan untuk kepentingan pergelaran masyarakat, dan panggung pertunjukan yang disiapkan untuk program tayangan televisi. Ada nuansa keakraban dalam sajian pertunjukan di masyarakat. Pemisahan tontonan dan penonton tidak terlihat ekstrem atau tegas. Panggung sering kali tertata oleh jajaran penonton yang memang memiliki ketertarikan langsung dengan sajian pertunjukan. Garis batas antara panggung dan penonton benar-benar tersamar dan tidak ada. Aliran sajian pertunjukan dikelola dengan babak-babak panggung yang disesuaikan dengan tuntutan pesan/content yang akan disampaikan. Pertunjukan menjadi lentur dan alami pada saat hadir di tengah masyarakat pendukungnya karena memang materi pertunjukan memiliki motivasi untuk mendidik, menghibur, dan menjaga harmoni kehidupan masyarakat.

Sulih mata adalah satu-satunya dasar pijak untuk melakukan pemahaman kehidupan seni pertunjukan pada saat dipersiapkan untuk kemasan siaran televisi. Kamera memang memiliki kelebihan optikal yang luar biasa dibanding dengan keterbatasan mata manusia. Akan tetapi, kamera memiliki keterbatasan pemahaman terhadap seni pertunjukan yang sedang digelar di depannya. Sifat objektif mata pada saat melihat panggung menjadi sifat subjektif kamera di tangan operatornya. Hal ini menjadi titik awal dari urgensi pemahaman terhadap seni pertunjukan yang sangat beragam di nusantara.

\section{Penutup}

Artikel ini ingin mengarahkan pandangan kritis pada beberapa kondisi penting yang layak dipertimbangkan pada saat mencermati seni pertunjukan, antara lain: Indonesia sangat potensial dalam kekayaan seni pertunjukan di setiap suku bangsa. Di balik kekayaan itu terbentang tantangan yang luas, bagaimana mengemas dan menyuguhkan kembali kepada masyarakat. Urgensi pencarian formula sinematografi untuk seni pertunjukan adalah potensi perubahan kehidupan budaya akibat industri media. Hasil kerja kreatif industri televisi dalam tayangan ketoprak humor, wayang kulit, extravaganza, Opera van Java, dan lain-lain memberikan pelajaran penting untuk dapat diformulasikan sebagai model. Pokok pencarian formula ini adalah tuntutan teknofisik dan teknokultural dalam gejala transkontekstualisasi seni pertunjukan pada saat harus menembus filter pengemasan format program di industri televisi. Melihat potensi seni media rekam untuk berperan dalam menyelamatkan kekayaan seni di Indonesia, di samping juga untuk menumbuhkan kebanggaan diri berbangsa dan bernegara. Karakteristik bangsa Indonesia dan potensi kesenian yang perlu arah.

\section{Kepustakaan}

Hampe, Barry. 1997. Making Documentary Films and Reality Videos. New York:

Henry Holt and Company.

Joseph V. Mascelli. The Five C's of Cinematography. California: Cine/Graphics Publication.

Manners, Robert A. 2002. Teori Budaya. Yogyakarta: Pustaka Pelajar.

Naratama. 2004. Menjadi Sutradara Televisi. Jakarta: Grasindo.

Wheeler, Paul. 2009. High Definition Cinematography. Amsterdam: Focal Press of Elsevier.

Tester, Keith. 2003. Media, Budaya, dan Moralitas. Yogyakarta: Juxtapose.

Thompson, Roy. Christopher J. Bowen. 2009. Grammar of the Shot (2nd edt.). Burmington: Focal Press.

Jurnal MSPI. 1996. Seni Pertunjukan Indonesia. Yogyakarta: Yayasan Bentang Budaya.

Jurnal Fotografi Televisi. Rekam 2. Yogyakarta: Fakultas Seni Media Rekam.

Jurnal Fotografi Televisi. Rekam 3. Yogyakarta: Fakultas Seni Media Rekam.

Majalah Seni Budaya GONG. "Lagu Dolanan Siapa"Gong Edisi 114/X/2009.

Majalah Seni Budaya GONG. "Menghitung Jari Fotografi Seni Pertunjukan"Gong Edisi $117 / \mathrm{X} / 2010$. 